\title{
Use of Edible Coatings to Increase the Shelf Life of Jaggery: A Review
}

\author{
B. Madhu ${ }^{1 *}$, S. Patel ${ }^{1}$, P. V. K. Jagannadha Rao ${ }^{2}$ and P. Sreedevi ${ }^{2}$ \\ ${ }^{1}$ Department of Agricultural Processing and Food Engineering IGKV, \\ Raipur-492012 (C.G.), India \\ ${ }^{2}$ AICRP on Post-Harvest Engineering and Technology, RARS, \\ Anakapalle-531 001 (A.P.), India \\ *Corresponding author
}

\section{Key w o r d s \\ Edible Coating, \\ Protein, \\ Polysaccharide, \\ Jaggery, Storage}

\section{Article Info}

Accepted:

20 May 2018

Available Online:

10 June 2018

\section{A B S T R A C T}

Jaggery, a sugar rich food product produced all over the world, is an important component in Indian diet, and it is consumed directly or used for preparation of sweet confectionery items. It is also used in many herbal and traditional medicines. India produces about 6 million tonnes of jaggery annually, which accounts $60 \%$ of the total production in the world; $65-70 \%$ of the total jaggery is from sugarcane, the remaining $30 \%$ is from palms. Jaggery is prepared predominantly by concentrating the sugarcane juice. It is available in the form of solid blocks as well as in semi-liquid form. In India, Production of jaggery starts from October and continues upto May, depending on the location. The total jaggery is produced is not consumed immediately after production, and is stored for a period of 10 to 12 months. The major problem associated with jaggery storage is the presence of invert sugars and mineral salts which being hygroscopic absorb moisture particularly during monsoon season when ambient humidity is high, and lead to spoilage. It has been estimated that more than $10 \%$ of jaggery produced in the country worth Rs.40 crores is lost every year due to deterioration. Drying of jaggery to reduce its initial moisture content is essential for storage. Attempts were made by several authors to prevent microbial growth and to increase the shelf life of jaggery based on wrapping or packaging in common packaging materials, in airtight containers, polyethylene and storage under ambient and refrigerated cold storage. Although many packaging materials have been studied with the aim of increasing shelf life, no data are yet available on applying edible coating and packaging under vacuum for a similar purpose. Edible films and coatings has been successfully used in various food applications e.g., in maintaining purity of fruits, providing functionality (e.g. glaze to chocolate), controlling adhesion, cohesion, barrier properties, extending shelf life and providing mechanical integrity to the product. However this technology is not well developed for protection of jaggery from spoilage. Edible films and coatings may extend the shelf life of jaggery produce by providing a semi-permeable barrier to gases and water vapour. The barrier would reduce respiration, enzymatic browning and loss of water from the product. Therefore, this article reviews research results of edible films/coatings prepared with hydrocolloids, lipids, waxes and composites over various food products including jaggery, formulation and application of edible coatings, and future trends, which is highly essential to develop techniques for the application of edible coatings/films to the jaggery, which may prevent the undesirable changes and increase the shelf life of jaggery during storage. 


\section{Introduction}

Sugarcane, Saccharum officinarum L., is an important commercial crop of India cultivated in an area of about 5.307 million hectares producing about 366 million tonnes of sugarcane annually (2014-15) (Anonmyous, 2016). In Andhra Pradesh, the crop is cultivated in an area of 0.21 million hectares producing about 13.9 million tonnes of sugarcane during the year, 2014-15 (Anonmyous, 2016). About $14.2 \%$ of total cane produced in A.P. is utilized for Jaggery and Khandsari preparation. Andhra Pradesh is one of the major producers of Jaggery in the country with well organised markets, the most prominent among which is located at Anakapalle.

Jaggery (also called as Gur in India, Desi in Pakistan, Panela in Mexico and South America, Jaggery in Burma and African countries, Hakuru in Sri Lanka, and NaamTaanOi in Thailand,) and khandsari are traditional Indian sweeteners, which are produced in addition to sugar from sugarcane (Jagannadharao et al., 2007). It is specially beneficial for people who are anemic, cannot eat or tolerate meat, suffering from frequent muscle cramps, tension or soreness, pregnant or experiencing pre-menstrual syndrome (PMS) symptoms and those have eaten too much salt can balance out their diets with jaggery (Jadhav et al., 2005).

Jaggery preparation involves extraction of juice from sugarcane, removal of lighter fraction comprising wax, carbon, undesirable solid particles and mud etc. by settling, followed by open pan boiling with added clarificant and removal of scum. Boiling is continued for 2 to 2.5 hours till the juice attains a temperature of $118^{\circ} \mathrm{C}$. As soon as the juice attains a temperature of $118^{\circ} \mathrm{C}$, properly concentrated juice is taken out of fire and is allowed for natural cooling with continuous stirring. After solidification the contents are transferred to wooden or aluminum moulds or earthenware pots. The shape of solid jaggery may vary from small round balls to large lumps. These are rectangular $(250 \mathrm{gm}-1 \mathrm{~kg})$, bucket shaped $(10-20 \mathrm{~kg})$ and trapezoidal lumps $(5 \mathrm{~kg})$, etc. After solidification the moisture content of solid jaggery reduces to $10-12 \%$ (d.b.). In India, jaggery is mainly produced in the month of November to April and stored for usage in off season (Uppal and Sharma, 1998). Cold storage godown is being used in west Godavari and Vishakhapatnam district of Andhra Pradesh, Kolhapur district of Maharashtra and Muzaffarnagar area of Uttar Pradesh (Jagannadha Rao et al., 2007).

Composition and storage conditions of jaggery (both physical and chemical) are important factors that determine the keeping quality of product. During storage, jaggery, basically suffers from four types of deterioration: physical, chemical, biological and microbiological. During storage, solid jaggery undergoes liquefaction and changed to dark colour, which was due to absorption of moisture and microbial attack (Kunte, 1952).

Physically, it destroys the texture through dissolution and liquefaction. It also dilutes the sugars and lowers the sweetness. Chemically, it promotes inversion of sucrose which in turn leads to loss of texture, structure and body hardness. Moisture gain also encourages microbial infection and degradation (Preethi Sukla, 2012). Fermentation brought about by yeasts and complex biological degradation caused by molds is the usual form of microbial degradation. Jaggery also becomes more hygroscopic at higher temperatures (Verma, 1985).

Storage of jaggery varies from region to region such as in earthen pots, wooden boxes, metal drums etc. Sometimes, without any container, heap of jaggery is just kept covered 
with cane trash, bagasse, wheat straw, cotton seed, furnace ash, palmyra leaf mat, rice husk etc., to protect the jaggery from ambient humidity.

Singh et al., (2009) advocated that for good keeping quality, moisture content of jaggery should not exceed $6 \%$ and it should be kept at a relative humidity of $43-61 \%$. It is very difficult to store jaggery during monsoon, especially in coastal areas of high rainfall and humidity. It is estimated that, about $5-10 \%$ of stored jaggery get spoiled every year leading to a colossal loss to the tune of 800 million rupees. Cold storage godown is being used in West Godavari and Visakhapatnam districts of Andhra Pradesh, Kolhapur district of Maharashtra and Muzaffarnagar area of Uttar Pradesh. Application of edible films or coating was done to protect the food from microbial decay. An ideal edible coating is the one that can extend storage life of fresh fruits and vegetables without causing anaerobiosis and reduces decay without affecting their quality (Akthar et al., 2015) or it is the thin layer of material which can be consumed and provide a barrier to oxygen, microbes of external source, moisture and solute movement for food (Baldwin., 1996; Park., 1999).

\section{Edible Coatings}

Edible coatings are used for extension of shelf life of fruits and vegetables and are environment friendly. These can also be safely eaten as part of the product and do not add unfavorable properties to the foodstuff (Baldwin et al., 1994). Edible coatings can enhance the shelf life of food products by reduction of moisture loss solute migration, gas exchange and reduction of physiological disorders. Also, edible coatings have high potential to control browning, discolour activity, off flavour, microbial activity and can extend shelf life (preethisukla, 2012; Dhall et al., 2013).

\section{History of Edible Coatings}

Edible coatings or edible films have been used for centuries in the food industry to preserve food products. This is not a new preservation technique. Wax was the first edible coating used on fruits. The Chinese applied wax coatings to oranges and lemons in the 12th and 13th centuries (Hardenburg, 1967).

\section{Characteristics of Edible Coatings}

Characteristics of edible coatings are based on their molecular structure, molecular size and its chemical composition (Arvanitoyanni and Gorris, 1999). A good edible coating should contain no toxic, allergic and non-digestible components, provide structural stability and prevent mechanical damage during handling, control water migration both in and out of protected food to maintain desired moisture content, provide semi-permeability to maintain internal equilibrium of gases involved in aerobic and anaerobic respiration, thus retarding senescence, prevent loss or uptake of components that stabilize aroma, flavor, nutritional and organoleptic characteristics necessary for consumer acceptance while not inversely altering the taste or appearance, provide biochemical and microbial surface stability while protecting against contamination, pest infestation, microbe proliferation, and other types of decay (Akthar, 2015).

\section{Advantages and Disadvantages of Edible Coatings}

The advantages of edible coatings are to reduce weight loss and firmness loss, decrease polymer packaging and waste, improve retention of acids, colour, flavour and sugar, maintain quality of fruits and vegetables during storage, and consumed along with fruits and vegetables, they contain health beneficial nutrients (Guilbert and Biquet, 
1996: Carriedo et al., 1992: Park, 1999). The disadvantages are edible coatings have good gas barrier properties which causes anaerobic respiration due to which normal ripening process is disturbed in fruits and vegetables, thick coating can prohibit oxygen exchange, causes off- flavour development and some edible coatings are hygroscopic in nature, which helps to increase microbial growth (Park et al., 1994: Ghaouth, 1991).

\section{Types of Edible Coatings}

Edible coating materials are generally made up of polysaccharides, proteins and lipids (Pascall and Lin 2013). The edible coatings are mainly divided into three classes i.e., Hydrocolloids: e.g., polysaccharides, proteins and alginate; Lipids: e.g., fatty acids, acryl glycerides; Waxes and Composites: e.g., protein/protein, polysaccharides/protein, lipid/polysaccharides (Donhowe and Fennema, 1993: Pramod et al., 2016).

\section{Protein Based Edible Coatings}

Protein based edible coatings are derived from animals and plants (Pramod et al., 2016). The plant based protein edible coating material are milk protein casein, whey protein, zein (from maize), gluten (from wheat), soy protein etc. and the animal based protein are egg albumen, collagen etc., (Baldwin, 1995).

\section{Whey Protein}

Whey protein is a byproduct from the cheese production and is particularly rich in $\beta$ lactoglobulin. Whey proteins $(20 \%$ of total milk proteins) when appropriately processed produce flexible but brittle films (Kaya and Kaya, 2000). It is used as a food supplement, as an alternative to milk for people with lactose intolerance, for replacing or supplementing milk-based infant formulas. Whey protein concentrate coating in combination with antibrowning agents effectively prolonged the shelf-life of minimally processed apple slices by two weeks when stored in packed trays at $3^{\circ} \mathrm{C}$ (Lee et al., 2003; Perez Gago et al., 2005).

\section{Gelatine}

Gelatine is a protein made from animal products. It is an important biopolymer derived from collagen and is extensively used by various industries because of its technological and functional properties. Gelatine is used for weight loss and for treating osteoarthritis, rheumatoid arthritis, and brittle bones (osteoporosis) and it is used for strengthening bones, joints, and fingernails. Also, it is used for improving hair quality and to shorten recovery after exercise and sports-related injury (Anonymous, 2016). The use of gelatin in the formation of films or coatings has been investigated by different authors on fruits and vegetables like carrots (Wang et al., 2015), cherry tomatoes (Zhang et al., 2016), oranges (Youssef et al., 2015), strawberries (Fakhouri et al., 2014), blueberry fruit (Feng et al., 2014) and pineapple fruit (Bizura Hasida et al., 2013).

\section{Corn Zein}

Corn Zein protein is effective to prevent colour change, firmness, weight loss and to increase the shelf life of fruits and vegetables. It has good barrier property to $\mathrm{O}_{2}$. Corn Zein coatings and films have excellent barrier property to water vapour; about 800 times higher than other edible coatings and wrapping films. All properties of zein coatings depend upon coating thickness (Park et al., 1994).

Park et al., (1994) revealed that corn- zein film delayed color changes, reduced weight loss, inhibited ethanol production, delayed 
ripening, and reduced firmness loss of tomatoes. The degree of color change was mainly dependent on the thickness of coating.

\section{Wheat Gluten}

Wheat gluten is composed mainly of gliadins and glutenins (alkali- and acid-soluble) fractions. Gliadin, the viscous component, constitutes a heterogeneous protein group characterized by single polypeptide chains associated by hydrogen bonding and hydrophobic interactions, having intramolecular disulfide bonds.

Glutenins form an extensive network of intermolecular disulfide bonds (HernandezMunoz et al., 2003). Strawberries with gluten coatings presented lower weight loss and softening when compared to uncoated ones (Tanada Palmu and Grosso, 2005).

\section{Soya Protein}

Most of the protein in soybeans is insoluble in water but soluble in dilute neutral salt solutions. Edible films based on soya protein can be produced in either of two ways: surface film formation on heated soymilk or film formation from solutions of soy protein isolate (SPI) (Gennadios and Weller, 1992). The use of soya protein in the formation of films or coatings on food products has been investigated by different authors (Baker et al., 1994; Gennadios et al., 1994; Stuchell and Krochta, 1994; Kunte et al., 1997; Rhim et al., 2000).

\section{Polysaccharide Based Edible Coating}

The most common polysaccharides used for edible coating of fruits and vegetables are starch, alginate, chitosan, cellulose, pullulan, carrageenan, gellan gum etc., (Han and Gennodios, 2005). Polysaccharides based edible coatings having poor moisture barrier properties and water soluble (Baiand Plotto, 2012).

\section{Starches}

Starches are polymers of d-glucopyranosyl, consisting of a mixture of the predominantly linear amylose and the highly branched amylopectin (Kramer, 2009). Application of starch films is limited by two major drawbacks. The films are often very brittle, requiring the presence of plasticizers to improve their flexibility (Peressini et al., 2003; Mali et al., 2004). Moreover, the high hydrophilicity of starch causes its barrier properties to decrease with increasing relative humidity; therefore, starch is not the best option when working with minimally processed fruits (Olivas and Barbosa Canovas, 2009).

Ariane et al., (2012) studied the effect of the three different levels of and carboxymethyl starch $(1,3$, and 5\%) on sensory characteristics of papayas during storage. The results indicated that the 3 and 5\% cassava starch coating gave greater brightness to the fruits. 5\% CMS favored the presence of fungi and damaged the fruit surface at the $14^{\text {th }}$ day of storage.

Fakhouri et al., (2007) evaluated the effect of the association of gelatin with suspensions of wheat native starch, sorghum, and potato on crimson grapes. The results for overall appearance, color, brightness and intention of purchase of the fruits with coating were higher in relation to the control (without coating).

\section{Alginates}

Alginates, which are extracted from brown seaweeds, are salts of alginic acid, a linear copolymer of d-mannuronic and l-guluronic acid monomers. Films can be formed either from evaporating water from an alginate gel or 
by a two-step procedure involving drying of alginate solution followed by treatment with a calcium salt solution to induce cross-linking (Janjarasskul and Krochta, 2010).

The strength and permeability of films may be altered by changing calcium concentration and temperature, among other factors (Kester and Fennema, 1986). Alginate based edible coating used on fresh-cut papaya pieces exhibited slightly improved water barrier properties for both types of coatings, as compared to the uncoated samples (Tapia et al., 2008).

\section{Chitosan}

Chitosan, a linear polysaccharide consisting of $\beta(1 \rightarrow 4)$ linked residues of $N$-acetyl-2-amino2-deoxy-d-glucose (glucosamine) and 2amino-2-deoxy-d-glucose ( $\mathrm{N}$-acetylglucosamine). Chitosan coatings were effective in extending shelf life of several fruits; reducing rates of water loss (Dong et al., 2004; Hernández-Muñoz et al., 2006; Chien et al., 2007; Lin et al., 2011), ascorbic acid loss (Dong et al., 2004; Chien et al.,
2007), softening (Ali et al., 2011), and enzymatic browning (Dong et al., 2004; Jiang et al., 2005); and delaying the ripening process by decreasing respiration rates (Ali et al., 2011; Lin et al., 2011).

\section{Cellulose and Its Derivatives}

Together with starch, cellulose and its derivatives (such as ethers and esters) are the most important raw materials for elaboration of edible films (Peressini et al., 2003). Cellulose, the most abundant natural polymer on earth, is an essentially linear natural polymer of $(1 \rightarrow 4)-\beta$-d-glucopyranosyl units. Methyl cellulose based coatings lower the water loss rate of fresh apricots and green peppers and inclusion of ascorbic acid or citric acid in the coating formulation as antioxidants lower the vitamin $\mathrm{C}$ loss (Ayranci and Tunc, 2004).

Avocados coated with methyl cellulose based coating demonstrates lower respiration rates, greener color and higher firmness as compared with the uncoated control during the entire storage (Maftoonazad and Ramaswamy, 2005)

Fig.1 Formulation of Edible Coating

$100 \mathrm{ml}$ distilled water + edible coating

(As per requirement)

Denaturation at $90^{\circ} \mathrm{c}$ (water bath) for 30 minutes<smiles>C1CC1</smiles>

Cooled at room temperature<smiles>C1=CC1</smiles>

Add 5\% glycerol

(Proper mixing)

$\vee$

Reheated at $50^{\circ} \mathrm{c}$ for 10 minutes

Apply on selected product 


\section{Gums}

Almost all gums are polysaccharides, consisting of sugars, which are used for preparation of edible coating on fruits and vegetables because of its texture capability and soluble in water. Generally, gums are divided into three types: (a) exudate gums (e.g., gum arabic), (b) extractive gums (e.g., guar gum) and (c) microbial fermentation gums (e.g., xanthan gum) (Mei Y. et al., 2002). Xanthan gums are prepared by microbial extraction by fermentation process. It is rapidly spread in water due to this high viscosity are found readily in cold and hot both stages. A mixture of gum arabic, guar gum and xanthan gum are used to form equal coatings with good adhesion property in wet batters (Mei Y. et al., 2002).

Ali et al., (2010) evaluated the performance of a novel coating based on gum arabic on tomato fruits. When compared to uncoated fruits, tomatoes coated with $10 \%$ gum arabic resulted in significant lower rates of changes in weight, colour, firmness, titrable acidity, soluble solids content, ascorbic acid content, and decay percentage.

\section{Lipid Based Edible Coating}

The lipid based edible coatings are being used from many years for preservation of fruits and vegetables. They provide shiny and glossy appearance to food. Lipids are having good water barrier capacity (Morillon et al., 2002). Most common lipid based coating materials are waxes, lacs, fatty acids and alcohols, acetylated glycerides and cocoa-based material.

\section{Waxes}

Waxes are esters of long-chain aliphatic acids with long-chain aliphatic alcohols (Rhim and Shellhammer, 2005). They are more resistant to water diffusion than most other edible film materials because of their very low content of polar groups (Kester and Fennema, 1986) and their high content in long-chain fatty alcohols and alkanes (Morillon et al., 2002). Addition of galctomannans in traditional wax based formulation of citrus fruits reduced weight loss of the fruit during respiration in a manner similar to a wax-based coating without gum (Chen and Nussinovitch, 2010).

\section{Acetylated glycerides}

Acetylation of glycerol monosterate by its reaction with acetic anhydride yields 1stearodiacetin. This acetylated monoglyceride displays the unique characteristic of solidifying from the molten state into a flexible, wax-like solid (Feugeet al., 1953).Most lipids in the solid state can be stretched to only about $102 \%$ of their original length before fracturing. Acetylated glycerol monostearate, however, can be stretched up to $800 \%$ of its original length (Jackson and Lutton, 1952), water vapor permeability of this film is much less than that of polysaccharide films with the exception of methyl cellulose or ethyl cellulose (Kester and Fennema, 1986).

A film formed by milk protein (casein) and lipid (acetylated monoglyceride) for lightly processed apples and potatoes was reported to provide protection from moisture loss and oxidative browning for up to three days (Baldwin et al., 1995).

\section{Composite Films}

Composites or multicomponent films and coatings contain combination of protein, polysaccharides and lipid based material. Edible films and coatings may be heterogeneous in nature, consisting of a blend of polysaccharides, protein, and/or lipids. This approach enables one to utilize the 
distinct functional characteristics of each class of film former (Kester and Fennema, 1986). The main objective of producing composite films is to improve the permeability or mechanical properties as dictated by the need of a specific application (Bourtoom T, 2008). The combination of gelatine with other biopolymers with different characteristics, such as whey proteins (Taylor et al., 2014), starch (Fakhouri et al., 2015), chitosan (Benbettaieb et al., 2016) or pectin (Gupta B et al., 2014), could be a good strategy for the development of films with improved mechanical and water resistance properties. A composite coating of WPC protein and rice bran oil with added glycerol as plasticizer effectively preserved the color, firmness, taste, and the overall acceptability of the fruits during storage (Hassani et al., 2012).

Bertan et al., (2005) found that composite edible/degradable films produced with hydrocolloids and lipids can result in better functionality than films produced with the components, especially with respect to their barrier properties. Of the lipids, waxes produce the best water vapor barrier properties, but produce fragile/brittle films. Films with the addition of acids, and the blend with elemi presented better water vapor barrier properties as compared to the gelatin/triacetin film. The mechanical resistance decrease with the addition of the lipids. However the opacity and soluble matter increased.

\section{Plasticizers}

Plasticizers contain low molecular weight, it is mixed with protein coating material for enhance and change its structural ability (Krochta, 2002: Sothernvit and Krochta, 2005). Water is also natural and effective plasticizer. The most common plasticizers added in coatings are glycerol, fatty acids, sorbitol, propylene glycol, sucrose polyethylene glycol and monoglycerides (Krochta and Johnson, 1997).

\section{Formation of Edible Coating}

As per the requirement, edible coating is dissolved in distilled water and mix thoroughly to form uniform solution. The solution is denatured at $90^{\circ} \mathrm{C}$ on water bath for 30 minutes to provide functionality to edible film. The solution is cool down to room temperature in chilled water. 5\% glycerol is added to solution as plasticizer and mix thoroughly. Then, the prepared solution is will be again reheated at $50^{\circ} \mathrm{C}$ for 10 minutes, then cooled to room temperature (Fig.1) (Mishra et al., 2016).

\section{Edible Coating Application Method}

Better uniform application of edible coating can be promoted by adding surfactants to solution to reduce surface tension. This strategy helps to reduce the superficial and in turn reduce water loss (Roth and Loncin, 1984). Edible coating should be applied on fruits and vegetables by dipping, brushing, extrusion, spraying and solvent casting.

The dipping method is used widely for applying edible coatings on fruits and vegetables, in this method fruits and vegetables are dipped in coating solution for 5-30 s (Valverde et al., 2005). Brushing method gives good result generally, edible Coatings applied on beans and highly perishable fruits and vegetables such as strawberry, berries. Spraying, extrusion and solvent castings are also used in food industry.

Extrusion method depends on thermoplastic properties of edible coatings and best technique for applying of edible coating for industrial purpose as compared to other methods (Pramod et al., 2016) 


\section{Effect of Edible Coatings on Shelf-life of Jaggery}

Preethi Sukla, (2012) studied the effect of whey protein edible coating of jaggery packed under different packaging materials and methods and stored at $30^{\circ} \mathrm{C}+1$ for 18 weeks on quality parameters of jaggery. The results indicated that the absorption of moisture and microbial attack could be overcome by applying protein based edible coating on jaggery, packing it under vacuum and storing it under controlled conditions of temperature and relative humidity.

Chand et al., (2013) studied the effect of edible coating of whey protein concentrate (WPC) on quality characteristics of jaggery stored in drying-cum-storage bin for 4 months and reported that the total effects of edible coating during storage was good in comparison to uncoated jaggery and concluded that edible coating of whey protein concentrate may be helpful in maintaining the quality and enhance the shelf life of jaggery.

Mishra et al., (2016) conducted studies on coating composed of carboxymethyl cellulose and whey protein concentrate on the storage characteristics of coated jaggery for 15 weeks, They concluded that coating of jaggery sample could help in retaining the desirable moisture upto some extent and the quality of jaggery could be overcome by applying edible coating based on carboxymethyl cellulose and whey protein concentrate.

\section{Future Trends}

The present day research in field of edible coating is focused on to develop technologies that ensure more precise control of coating properties and functionality (Siddharth Agarwal and Prachi Mittal, 2014). Most of these new methodologies are based on composite or multilayered systems. A possible multilayered structure could include three layers: a matrix layer (e.g. based on biopolymer like alginate, chitosan etc) that contains the functional substance; an inner control layer that regulates the diffusion rate of the functional substance by ensuring its controlled release; and a barrier layer that controls the permeability to gases and prevents the migration of the active agent from the coated food (Gennadios, 2002).

Herbal edible coating is a new technique for food industry, which is made from herbs or combination of other edible coatings and herbs. The most common herbs used in edible coatings are such as aloe vera gel, neem, lemon grass, rosemary, tulsi and turmeric. Herbs have antimicrobial properties, and consist of vitamins, antioxidants and essential minerals (Douglas et al., 2005).

The most recent approach to improve coating properties is to make nanocomposites by incorporating nano sized clay such as layered silicates into biopolymer based matrices (Siddharth Agarwal and Prachi Mittal, 2014). The composites with better mechanical, water vapour barrier, and antimicrobial properties than the traditional chitosan coatings, which can be achieved incorporating different nanoparticle (montmorillonites, nano-silver, and silver-zeolite) into chitosan matrix (Rhim et al., 2006).

In conclusion, India is the largest producer of jaggery under unorganized agro processing sector, sharing $60 \%$ of the world production, engaging over 2.5 million people in rural India. Jaggery is very critical to store due to presence of salts and reducing sugars, which are hygroscopic in nature. Jaggery losses to the tune of $10-25 \%$ during storage and is always a big problem during summer and rainy seasons. The jaggery manufacturers are mostly small and marginal farmers relying on quick returns from jaggery. It is, therefore, 
essential to safeguard the jaggery manufacturers to earn more profit from their jaggery manufacturing unit. The technologies adopted so far for the storage of various food products including jaggery with various edible coatings and also regarding use of multilayered or herbal based edible coatings to ensure more precise control of coating properties and functionality was reviewed and presented. Various studies have suggested that, whey protein edible coating over jaggery could increase the shelf life of the jaggery during humid season and could reduce the degradation of physical and chemical qualities of jaggery as well. Hence, the need for research on new edible coatings/films with improved functionality and performance is highly essential to understand the mechanism of the effect of edible coatings/films for handling and storage of jaggery without loss of quality.

\section{References}

Ali, A, Muhammad, M.T., Sijam, K, and Siddiqui, Y. 2011. Effect of chitosan coatings on the physicochemical characteristics of Eksotika II papaya (Carica papaya L.) fruit during cold storage. Food Chemistry., 124: 620626.

Ali, A., Maqbool M., Ramachandran S., and Alderson P.G. 2010. Gum arabic as a novel edible coating for enhancing shelf-life and improving postharvest quality of tomato (Solanum lycopersicum L.) fruit. Postharvest Biology and Technology., 58: 42-47.

Alparslan, Y., Yapici, H.H., Metin, C., Baygar, T., Gunlu, A., Baygar, T. 2016. Quality assessment of shrimps preserved with orange leaf essential oil incorporated gelatin. Food Sci. Technol., 72: 457-466.
Ananymous.

2016

www.webmd.com/vitaminssupplements.

Ariane, C, Regina, C.C., Rosires, D. 2012. Starch edible coating of papaya: effect on sensory characteristics. Cienc. Tecnol. Aliment. Campinas., 32(1): 8492.

Bai, J. and Plotto, A., 2012. Coating for fresh fruits and vegetables, In edible coating and films to improve food quality, Edited by JinheBai CRC Press., 186248.

Baker, R. A., Baldwin, E. A., and Nisperos Carriedo, M. O. 1994. Edible coatings and films for processed foods. In Krochta, J.M., Balwin, E. A. and Niperos-Carriedo M.O. (Eds.). Edible Coatings and Films to Improve Food Quality, Lancaster, Basel: Technomic Publishing., 89-104.

Baldwin, E.A, Nesperos Carriedo, M.O., Chen, X. and Hagenmaier, R.D. 1996. Improving storage life of cut apple and potato with edible coating, Postharvest Bio. Technol., 9:151-163.

Baldwin, E.A. 1994. Edible coating for fresh fruits and vegetables: past, present and future. In : Krochta J.M., Baldwin E.A., Nisperos Carreido M.O. (eds), Edible coating and films to improve food quality, Techonomic publishing company, Inc., Lancaster, Pennsylvania, USA, 25-64.

Baldwin, E.A., Nesperos Carriedo, M.O. and Baker, R.A. 1995. Use of edible coating to preserve quality of lightly and slightly processed product, Criti. Rev. Food Sc. Nutri. 35:509-552.

Benbettaieb, N., Chambin, O., Karbowiak, T. and Debeaufort, F. 2016. Release behavior of quercetin from chitosan-fish gelatin edible films influenced by electron beam irradiation. Food Control., 66: 315-319. 
Bertana, L.C., Tanada-Palmua, P. S., Sianib A. C. and Grosso C.R.F. 2005. Effect of fatty acids and 'Brazilian elemi' on composite films based on gelatin. Food Hydrocolloids 19:73-82.

Bizura Hasida, M.R., Nur Aida, M.P., Zaipun, M.Z., Hairiyah, M. 2013. Quality evaluation of fresh-cut "josapine" pineapple coated with hydrocolloid based edible coating using gelatin. Acta Hortic., 1012: 1037-1042.

Bourtoom, T. 2008. Edible films and coatings: characteristics and properties.International Food Research Journal 15(3): 237-248.

Cantwell, M.A., and Suslow T.V. 2002. Post harvest handling systems: fresh-cut fruits and vegetables. In: Postharvest Technology of Horticultural Crops, Kader AA $\left(3^{\text {rd }}\right.$ Edn), Agric Natural Res Publ, CA, USA.

Chien, P.J., Sheu F., and Yang F.H. 2007. Effects of edible chitosan coating on quality and shelf life of sliced mango fruit. Journal of Food Engineering., 78: 225-229.

Cuq, B., Gontard N, and Guilbert S. 1998. Proteins as agricultural polymers for packaging production.Cereal Chemistry 75(1): 1-9.

Dhall, R.K. 2013. Advances in Edible Coatings for Fresh Fruits and Vegetables: A Review, Critical Reviews in Food Science and Nutrition, 53(5):435-450.

Dong, H., Cheng, L., Tan, J., Zheng, K., and Jiang Y. 2004. Effects of chitosan coating on quality and shelf life of peeled litchi fruit. Journal of Food Engineering., 64: 355-358.

Donhowe, I.G., and Fennema O.R., 1993. The effect of plasticizers on crystallinity, permeability and mechanical properties of methylcellulose films, J. of Food Processing and Preservation., 17:247257.
Fakhouri, F.M., Casari, A.C.A., Mariano, M., Yamashita, F., Mei, L.H.I., Soldi, V. and Martelli, S.M. 2014. Effect of a gelatin-based edible coating containing cellulose nanocrystals (CNC) on the quality and nutrient retention of fresh strawberries during storage. IOP Conf. Ser. Mater. Sci. Eng., 64.

Fakhouri, F.M., Martelli, S.M., Caon, T., Velasco, J.I. and Mei, L.H.I. 2015. Edible films and coatings based on starch/gelatin: Film properties and effect of coatings on quality of refrigerated red crimson grapes. Postharvest Biol. Technol., 109: 57-64.

Feng, D., Zhengguang, W., Yimei, Z., Xiang, Z., Meng, G.X., Xu, Y., and Bi, Y. 2014. Effect of chitosan composite coating on chinese blueberry fruit (Vaccinium uliginosum L.). Acta Hortic., 1053: 207-214.

Feuge, R. O., Vicknair E. J. and Lovegren N. V. 1953.Modification of vegetable oils. XIII. Some additional; properties of acetostearin products. Journal of the American Oil Chemists' Society., 30: 283.

Gennadios, A. 2002. Protein-based films and coatings: CRC Press.

Gennadios, A., and Weller C. L. 1992. Tensile strength increase of wheat gluten films. International Winter Meeting American Society of Agricultural Engineers., Nashvill, TN.

Gennadios, A., McHugh, T. H., Weller, C. L. and Krochta, J. M. 1994. Edible coating and films based on protein. In Krochta, J. M., Balwin, E. A. and NiperosCarriedo, M. O. (Eds.). Edible Coatings and Films to Improve Food Quality. Lancaster. Basel: Technomic Publishing., 201-277.

Ghaouth, E. 1., Arul J., Ponnampalam R. and Boulet M. 1991. Chitosan coating effect on stability of fresh Strawberries, $J$. Food Sc. 57:1618-1620. 
Gupta, B., Tummalapalli, M., Deopura, B.L. and Alam, M.S. 2014. Preparation and characterization of in-situ crosslinked pectin-gelatin hydrogels. Carbohydr. Polym., 106: 312-318.

Hardenburg, R.E, 1967. Wax and related coatings for horticultural products-a bibliography. Agricultural Research Service Bulletin., 51-55.

Hassani, F., Garousi, F. and Javanmard, M. 2012. Edible coating based on whey protein concentrate-rice bran oil to maintain the physical and chemical properties of the kiwifruit (actinidia deliciosa). Trakia Journal of Sciences., 10(1): 26-34.

Jackson, F. L. and Lutton, E. S., 1952. The polymorphism of 1-stearyl and 1palmityldiacetin dibutyrin,-dicaproin and 1-stearyldipropionin. Journal of the American Oil Chemists' Society 74: 4827-4831.

Jagannadha Rao, P.V.K., Madhuswetha Das and Das S.K. 2007. Jaggery - a traditional Indian sweeter. Indian journal of traditional knowledge., 6(1): 95-102.

Janjarasskul, T. and Krochta, J.M. 2010. Edible packaging materials.Annual Review of Food Science and Technology 1: 415-448.

Javeed Akhtar, Omre P.K. and Ahmad Azad Z.R.A. 2015. Edible Coating for Preservation of Perishable Foods: A Review, Journal Of Ready To Eat Food., Vol 2:81-88.

Jiang, Y., Li, J., and Jiang, W. 2005. Effects of chitosan coating on shelf life of coldstored litchi fruit at ambient temperature. LWT-Food Science and Technology 38: 757-761.

Kester, J.J. and Fennema, O.R. 1986. Edible films and coatings: A review. Food Technology 40: 47-59.

Khan Chand, Verma, A. K, Anil Kumar, and Shahi N. C. 2013. Effect of Edible
Coating on Quality Parameters of Jaggery during Storage. $A n$ International Journal of Sugar CropsAnd Related Industries.

Kramer, M.E. 2009. Structure and function of starch-based edible films and coatings. In Edible Films and Coatings for Food Applications, eds. M.E. Embuscado and K.C. Huber, pp. 113-134.

Krochta, J.M. 2002. Protein as raw material for films and coating: definition, current status and opportunities in protein based films and coatings, Edited by Gannedios, A., CRC Press L. L. C., 1141.

Krochta, J.M. and Mulder Johnson C. 1997. Edible and biodegradable polymer films challenges and opportunities, Food tech., 52:661-74.

Kunte, L. A., Gennadios, A., Cuppett, S. L., Hanna, M. A. and Weller, C. L. 1997. Cast films from soy protein isolates and fractions. Cereal Chemistry., 74: 115118.

Kunte, M.V. 1952. Studies in the absorption of moisture by gur (jaggery) during storage".M.Sc. Thesis, University of Poona, Pune.

Lee, J, et al., 2003. Extending shelf-life of minimally processed apples with edible coatings and antibrowning agents. LWT. 36, 323-329.

Lin, B., Du, Y., Liang, X., Wang, X., Wang, X., and Yang, J. 2011. Effect of chitosan coating on respiratory behavior and quality of stored litchi under ambient temperature.Journal of Food Engineering 102: 94-99.

Mali, S., Grossmann, M.V.E., García, M.A., Martino, M.M., and Zaritzky, N.E. 2004. Barrier, mechanical and optical properties of plasticized yam starch films.Carbohydrate Polymers 56: 129135.

Mei, Y., Yang, J., and Fun, H.R. 2002. J. Food Sc., 67:1964-1968. 
Mishra Ritesh, Omre P.K., Khan Chand, Sanjay Kumar and Ankur Singh Bist. 2016. Efficacy of a coating composed of carboxymethyl cellulose And whey protein concentrate to control the quality of Jaggery. International journal of engineering sciences and research Technology. ISSN: 2277-9655 (I2OR).

Morillon, V., Debeaufort F., Blond G., Capelle M. and Voilley A. 2002. Factors affecting the moisture permeability of lipid based edible films: A review, Criti. Rev. in food Sci. and Nutr., 42(1):67-89.

Nesperos Carriedo, M.O., Baldwin E.A., and Shaw P.E. 1992. Development of an edible coatings for extending postharvest life of selected fruits and vegetables. Proc. Annual Meeting Fla. State Hort. Soc., 104:122-125.

Olivas, G.I., and Barbosa Canovas, G. 2009. Edible films and coatings for fruits and veg etables. In Edible Films and Coatings for Food Applications, eds. M.E. Embuscado and K.C. Huber, pp. 211-244.

Park, H.J. 1999. Development of advanced edible coating of fruits, Trends of Food Sc. and Techno., 10:250-260.

Park, J.W., Testin R.F., Rank H.J, Vergano P.I., and Wlter C.I. 1994. Fatty acid concentration effect on textile strength, elongation and water vapour permeability of laminated edible films, J. Food Sc., 59: 916-919.

Pascall, and Lin, S.J. 2013. The application of edible polymeric film and coating in the food industry, J. of food proc. and tech., 4:116.

Peressini, D., Bravin, B., Lapasin, R., Rizzotti, C., and Sensidoni, A. 2003. Starch-methylcellulose based edible films: Rheological properties of filmforming dispersions. Journal of Food Engineering 59(1): 25-32.
Perez Gago, M.B., Serra, M., Del Rio M.A., 2006. Color change of fresh-cut apples coated with whey protein concentratebased edible coatings. Postharvest Biology and Technology., 39: 84-92.

Pramod, K. R., Nidhi Agarwal and Mitu Saini, 2016. Edible coating of fruits and vegetables: a review. International Journal of Scientific Research and Modern Education., 1(1): 188-204.

Preeti Shukla, 2012. Effect of edible coating and packaging on microbiological characteristics of jaggery.Prime Journal of Microbiology Research., 2(4): 121125.

Rhim, J. W., Gennadios, A., Handa, A., Weller, C. L. and Hanna, M.A., 2000. Solubility, tensile, and color properties of modified soy protein films. Journal of Agricultural and Food Chemistry., 48: 4937-4941.

Rhim, J.W., Hong, S.I., Park, H.M. and Ng, P. K. 2006. Preparation and characterization of chitosan-based nanocomposite films with antimicrobial activity. Journal of Agricultural and Food Chemistry., 54(16): 5814-5822.

Siddharth Agarwal and Prachi Mittal. 2014. Recent Trends in Edible Films and Coatings for Fresh and Minimally Processed Fruits. The International Journal of Science and Technoledge., 2(12): 239-244.

Singh, S., Dubey, A., Tiwari, L. and Verma, A.K. 2009. Microbial profile of stored jaggery: a traditional Indian sweetener. Sugar Tech., 11: 213-216.

Sothernvit, R. and Krochta, J.M. 2005. Plasticiser in edible films and edible coating, In: innovation in food packaging, Edited by Jung H. Han, USA Elsevier Academic Press., 403433.

Tanada Palmu, P.S. and Grosso, C.R.F. 2005. Effect of edible wheat gluten-based films and coatings on refrigerated 
strawberry (Fragaria ananassa) quality. Postharvest Biology and Technology., 36: 199-208.

Tapia, M. S., Rojas Graü, M. A., Carmona, A., Rodriguez, F. J., Soliva Fortuny, R. and Martin Belloso, O. 2008. Use of alginate-and gellan-based coatings for improving barrier, texture and nutritional properties of fresh-cut papaya. Food Hydrocolloids., 22(8): 1493-1503.

Taylor, M.M., Lee, J., Bumanlag, L.P., Latona, R.J. and Brown, E.M. 2014. Biopolymers produced from gelatin and whey protein concentrate using polyphenols. J. Am. Leather Chem. Assoc., 2014(109): 82-88.

Uppal, S.K. and Sharma S., 1998. Evaluation of different methods of jaggery (gur) storage in sub-tropical region. Ind. $J$. Sugarcane Tech., 13(9): 73-79.

Valverde, J.M., Valesa, D., Martinez Romero, D., Gullen, F.N., Cartillo, S. and Serrano M., 2005. Novel edible based on Aloe veragel to maintain table
Grapes quality and safety, J. of Ag. and Food Chem., 53:7807-7813.

Wang, X., Kong, D., Ma, Z. and Zhao, R., 2015. Effect of carrot puree edible films on quality preservation of fresh-cut carrots. Irish J. Agric. Food Res., 5: 6471.

Weiss, J., Takhistov, P. and McClements, D.J. 2006. Functional materials in food nanotechnology. Journal of Food Science., 71(9): R107-R116.

Youssef, A.R.M., Ali, E.A.M. and Emam, H.E. 2015. Influence of postharvest applications of some edible coating on storage life and quality attributes of navel orange fruit during cold storage. Int. J. Chem. Technol. Res., 8:21892200.

Zhang, B., Feng, X., Han, P. and Duan, X., 2015. Effect of propolis/nano-silica composite coating on activities of ripening and senescence related enzymes in cherry tomato fruits. $J$. Chin. Inst. Food Sci. Technol., 16: 159165.

\section{How to cite this article:}

Madhu B., S. Patel, P. V. K. Jagannadha Rao and Sreedevi P. 2018. Use of Edible Coatings to Increase the Shelf Life of Jaggery: A Review. Int.J.Curr.Microbiol.App.Sci. 7(06): 2466-2479. doi: https://doi.org/10.20546/ijcmas.2018.706.293 